\title{
Identification of structures containing polyphosphate in Helicobacter pylori
}

\author{
G. Bode, ${ }^{*}$ F. Mauch, H. Ditschuneit and P. Malfertheiner \\ Department of Internal Medicine I, University of Ulm, Robert-Koch-Str. 8, D-89081 Ulm, Germany
}

(Received 26 February 1993; revised 9 June 1993; accepted 14 June 1993)

\begin{abstract}
For the first time polyphosphate (poly P) granules have been detected in Helicobacter pylori organisms colonizing the gastric antrum as well as in organisms isolated from the same tissue. Poly $P$ granules showed typical sublimation characteristics during exposure to the electron beam and chipped out of ultrathin sectioning. A prominent phosphorus signal was identified using elemental specific electron microscopy such as electron energy loss spectroscopy (EELS) and was localized to at least three different locations: the cytoplasm, the flagellar pole and in association with the cell membrane. Intracytoplasmatic structures had a diameter of 0.05-0.2 $\mu \mathrm{m}$, whereas the structures near the flagellar pole were much smaller $(0.02 \mu \mathrm{m})$. The membrane-associated phosphate aggregates were visible only after staining with $\mathrm{Pb}\left(\mathrm{NO}_{3}\right)_{2}$ or with electron spectroscopic imaging (ESI). Poly $\mathrm{P}$ granules seem to be important energy and phosphorus stores and it is thought that they participate in the regulation of various and distinct metabolic processes of $\boldsymbol{H}$. pylori.
\end{abstract}

\section{Introduction}

Little is known about the basic metabolism of Helicobacter pylori and how this organism gains energy from substances that are naturally available in the stomach. However, nutrients from the stomach lumen seem not to be the major energy source for these bacteria, because they are normally found within the mucus layer, deep in the gastric pits or in association with epithelial cells (Hazell et al., 1986; Bode et al., 1988).

In the laboratory, $H$. pylori is grown on relatively nutrient rich and supplemented culture media. The culture techniques used have 'domesticated' $H$. pylori by providing optimal conditions for growth, rather than addressing the real need for growth and energy supply. $H$. pylori grows on enriched media containing complex organic constituents such as blood, peptones and yeast extract, and some of them, such as soluble starch, foetal calf serum and activated charcoal, stimulate growth (Buck \& Smith, 1987; Westblom et al., 1991). A salient observation is that $H$. pylori can grow on media essentially free of carbohydrates. The inability to oxidize or ferment sugars is a characteristic feature shared by

*Author for correspondence. Tel. +497315023445; fax +49731 5022038

Abbreviation: Poly P, polyphosphate. most members of the genus Campylobacter (Tompkins et al., 1989).

H. pylori possesses a prominent urease activity, the prime function of which is to supply nitrogen from urea. How $H$. pylori fulfils its carbon and energy needs is still not known. Nor are there data available which shed light on the phosphorus supply of $H$. pylori. In this paper, we describe for the first time the presence of polyphosphate (poly P) aggregates in H. pylori cells. Our purpose was to identify and characterize structures in $H$. pylori by histochemical and electron microscopic techniques.

\section{Methods}

During endoscopy, antral biopsies were obtained from the lesser gastric curvature of $H$. pylori-positive patients. Tissue samples were used for histology and electron microscopy, for isolating H. pylori, and for the urease test (CU-Test, Temmler Pharma).

Growth medium and culture conditions. Biopsies for culture were placed in a transport medium (Port-a-CUL, Becton-Dickinson) and homogenized immediately. The homogenates were plated on WilkinsChalgren blood agar plates, supplemented using the method of Skirrow (1977). Cultures were incubated at $37^{\circ} \mathrm{C}$ for 2 to $3 \mathrm{~d}$ under microaerophilic conditions. For subculturing, strains were transferred into liquid media containing Brucella broth (Difco) and $6 \%(\mathrm{v} / \mathrm{v})$ foetal calf serum and incubated for $2 \mathrm{~d}$ under constant conditions in a shaking incubator. H. pylori strains were identified by routine microbiological tests. 


\section{Electron microscopy}

Tissue samples were fixed for $2 \mathrm{~h}$ in $2.5 \%(\mathrm{v} / \mathrm{v})$ glutaraldehyde (cacodylate buffer $0 \cdot 1 \mathrm{M}, \mathrm{pH} 7 \cdot 4$ ). After washing in buffer, samples were fixed in buffered $2 \%(\mathrm{w} / \mathrm{v}) \mathrm{OsO}_{4}$ solution for a further $2 \mathrm{~h}$. After thorough washings, the tissue was dehydrated and block stained with uranyl acetate. After embedding in Epon 812, sections were additionally stained with lead citrate.

Cultured $H$. pylori were analysed for the presence of polyphosphate granules by various electron microscopic methods.

Ultrathin sections. Preparation of cultured $H$. pylori for electron microscopy was carried out according to the method described for tissue samples.

Polyphosphate staining. The specific staining of polyphosphates was carried out by a method described by Jensen (1968). After fixation in cacodylate-buffered $2.5 \%(\mathrm{v} / \mathrm{v})$ glutaraldehyde $(\mathrm{pH} 7 \cdot 4,0.1 \mathrm{~m})$, cells were thoroughly washed and placed in $20 \%(\mathrm{w} / \mathrm{v}) \mathrm{Pb}\left(\mathrm{NO}_{3}\right)_{2}$ for $4 \mathrm{~h}$ at $\mathrm{pH} 3.5$ (adjusted with $0 \cdot 1 \%$ acetic acid) and then in $1 \%(\mathrm{w} / \mathrm{v})\left(\mathrm{NH}_{4}\right)_{2} \mathrm{~S}$ for $30 \mathrm{~min}$. Each step was followed by rinsing with distilled water. Another set of samples were postfixed with a $1 \%(\mathrm{w} / \mathrm{v}) \mathrm{OsO}_{4}$ solution. Some samples were treated with ice-cold $10 \%(\mathrm{v} / \mathrm{v})$ trichloracetic acid (TCA) to extract polyphosphates and then stained according to the procedure described above.

Element-specific electron microscopy. For electron spectroscopic imaging (ESI) and electron energy-loss spectroscopy (EELS), ultrathin sections $(15-25 \mathrm{~nm})$ were collected on uncoated 700 mesh grids and examined without further staining in a CEM 902 spectroscopic electron microscope (Carl Zeiss) equipped with an image analysis system from Kontron.

The EELS spectra of poly $\mathrm{P}$ aggregates were recorded with an integrated prism-mirror spectrometer. A photomultiplier system (PMT) recorded the electron intensities. The analogue signals of the detector were digitized by a digital multimeter (Hameg Instruments) and fed into a computer in order to plot relative intensities against corresponding energy losses. To reduce beam damage, areas for spectra recording were selected with a reduced beam current. Elements were identified by analysing the specific energy losses of electrons that are scattered by the atoms of the investigated structures. ESI shows the local distribution and variations in concentration of a selected element using the specific energy loss of the electrons (Harauz \& Ottensmayer, 1984; Bauer, 1988).
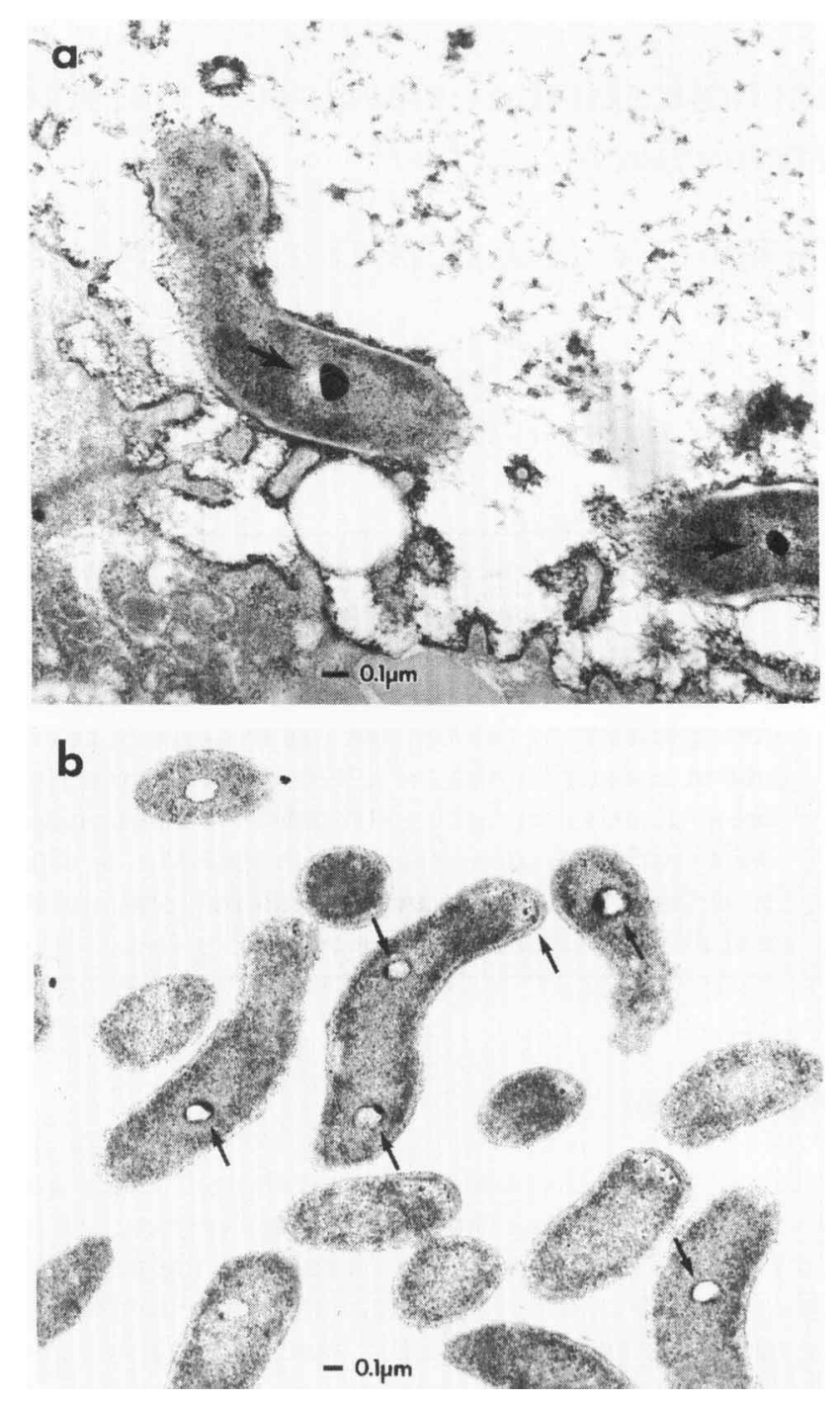

Fig. 1. (a) H. pylori in association with gastric surface mucus cells. Electron dense poly $\mathbf{P}$ granules with typical appearance are arrowed. Ultrathin section. (b) Cultured H. pylori organisms isolated from gastric tissue shown in (a). Poly $\mathrm{P}$ granules are arrowed. Ultrathin section.

Table 1. Characteristic features of polyphosphate aggregates of H. pylori

Five different strains were investigated.

\begin{tabular}{|c|c|c|c|c|}
\hline \multirow{2}{*}{$\frac{\text { Location }}{\text { Cytoplasm }}$} & \multirow{2}{*}{$\frac{\text { Size }}{0.05-0 \cdot 2 \mu \mathrm{m}}$} & \multirow{2}{*}{$\begin{array}{c}\text { Morphology } \\
\begin{array}{c}\text { Amorphous, } \dagger, \\
\text { vacuole-like }\end{array}\end{array}$} & \multicolumn{2}{|c|}{ Function* } \\
\hline & & & $\begin{array}{l}\text { Energy and } \\
\text { phosphorus } \\
\text { reservoir }\end{array}$ & $\begin{array}{l}\text { (Dawes, 1973; Harold, 1966; } \\
\text { Kulaev \& Vagabov, 1983; } \\
\text { Wood \& Clark, 1988) }\end{array}$ \\
\hline $\begin{array}{l}\text { Flagellar } \\
\text { pole }\end{array}$ & $0.02 \mu \mathrm{m}$ & $\begin{array}{l}\text { Compact, } \\
\text { homogeneous }\end{array}$ & Motility (?) & (Eisenbach, 1990) \\
\hline $\begin{array}{l}\text { Membrane } \\
\text { associated }\end{array}$ & $>0.01 \mu \mathrm{m}$ & $\begin{array}{l}\text { Electron denset } \\
\text { reaction with } \\
\mathrm{Pb}\left(\mathrm{NO}_{3}\right)_{2} ; \\
\text { detection by } \\
\text { ESI }\end{array}$ & $\begin{array}{l}\text { Phosphorylation } \\
\text { and transport } \\
\text { processes (?) }\end{array}$ & (Skorko, 1989) \\
\hline
\end{tabular}

* Supposed function according to the literature cited.

† Typical polyphosphate granules: 'exploding' in the electron beam and chipping out during sectioning.

$\$$ Visible only after the application of specific methods. 


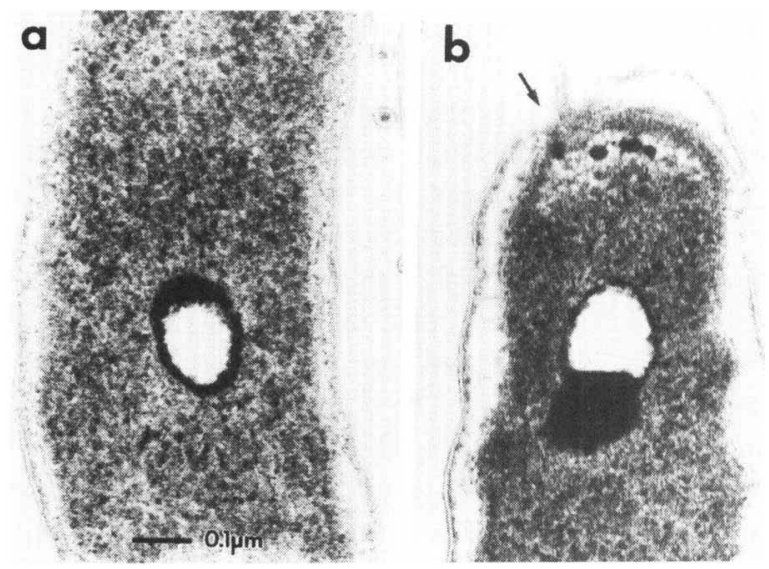

Fig. 2. Characteristic appearance and localization of poly P. Ultrathin sections. (a) Large, intracytoplasmatic bodies; (b) small, compact particles at the flagellar pole (arrowed).

\section{Results}

\section{Conventional electron microscopy}

In tissue samples of patients, poly $\mathrm{P}$ granules could be detected in four of the five strains examined. Fig. 1(a) shows prominent highly electron dense structures within the cytoplasm which often tend to chip out in sections. Cultured $H$. pylori also showed these characteristic structures.

The electron dense structures have clear-cut margins which do not seem to possess a bounding membrane (Fig. $1 b$ ). Nevertheless, they were markedly different in their shape and morphological organization. Some of the poly $\mathbf{P}$ granules may be loosely packed, leading to an amorphous appearance. Some were more compact and electron opaque. Even for granules displaced during cutting the margins of the granules were sharp. After exposure of the granules to high electron beam intensity, they showed sublimation characteristics and disintegration depending on the time of exposure. This phenomenon was not so obvious in smaller granules.

$H$. pylori organisms contained different classes of poly $\mathbf{P}$ granules. They may be subdivided according to their structure and size and/or according to their location (Table 1).

The largest granules were found within the cytoplasm and had a range of diameters from $0.05 \mu \mathrm{m}$ to $0.2 \mu \mathrm{m}$. The granules close to the flagellar pole were relatively homogeneous in morphology and size with an average diameter of about $0.02 \mu \mathrm{m}$ (Fig. 2).

Other poly $\mathbf{P}$ stores could be detected only after specific staining with lead salts. The application of $20 \%$ $(\mathrm{w} / \mathrm{v}) \mathrm{Pb}\left(\mathrm{NO}_{3}\right)_{2}$ at low $\mathrm{pH}$ demonstrated reaction product in association with the cell membrane of $H$. pylori cells. These structures were generally smaller than the other granules (Fig. $4 a$ ).

\section{Element specific electron microscopy}

Electron energy loss spectroscopy of poly $\mathrm{P}$ granules demonstrated the presence of phosphorus (Fig. $3 a$ ). The EEL spectrum of an intracytoplasmatic granule
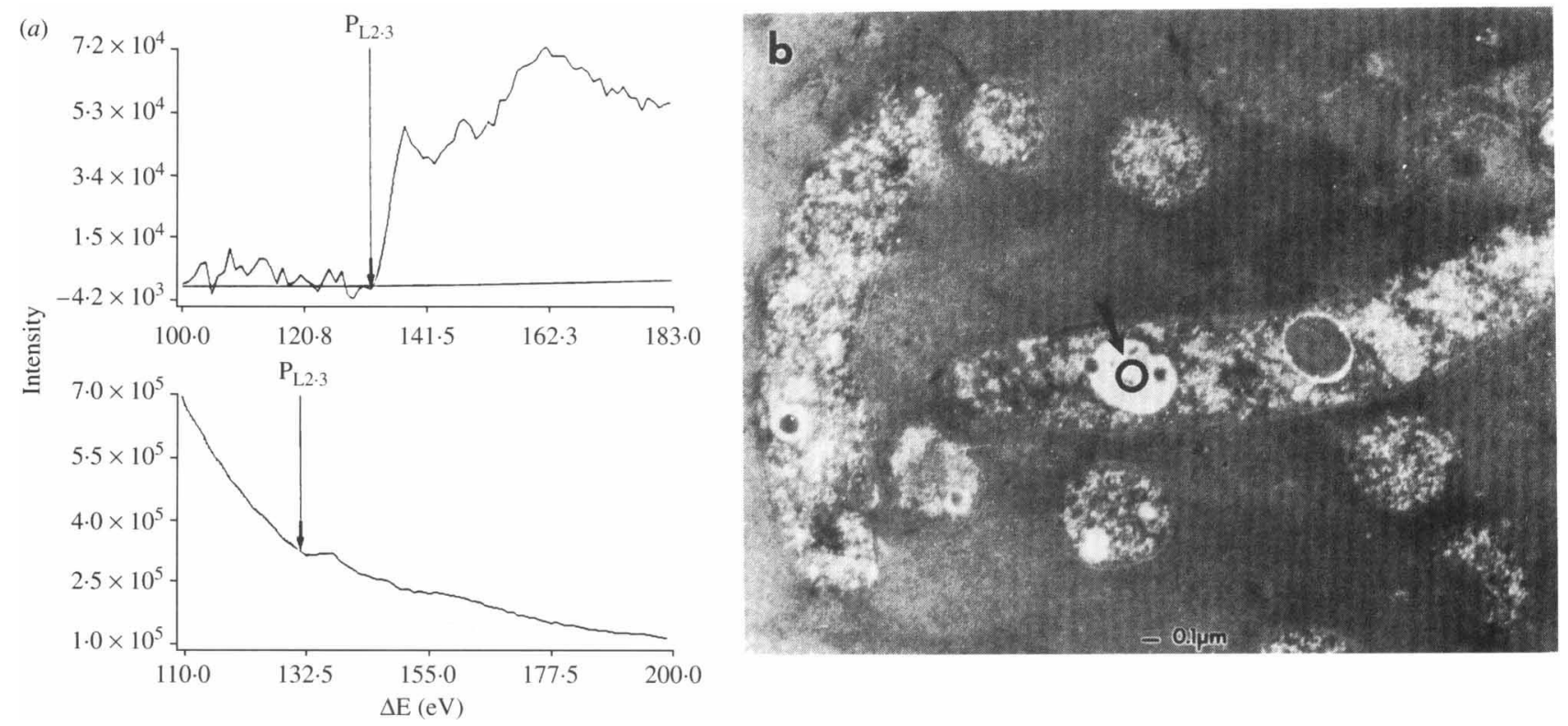

Fig. 3. Element specific electron microscopy of poly P granules. (a) Electron energy loss spectra (EELS) of phosphorus after subtraction of the background (upper panel) and the extrapolated version (lower panel). The spectra were obtained by analysing the encircled area in $(b)$. Electron spectroscopic imaging (ESI) of $H$. pylori cells showing elemental mapping of phosphorus using the specific energy loss of phosphorus $(132 \cdot 5 \mathrm{eV})$. 

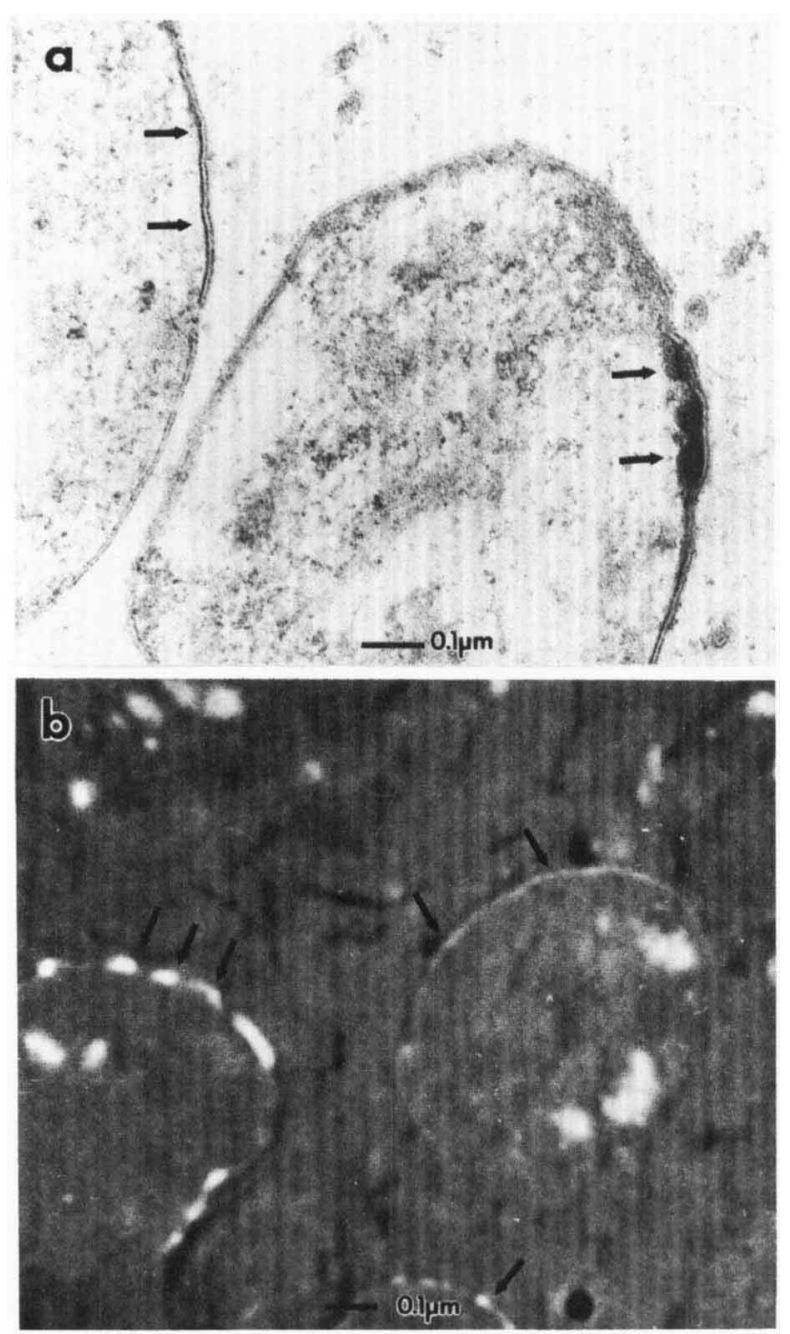

Fig. 4. Poly P stores in association with the cell membrane. (a) Staining with $\mathrm{Pb}\left(\mathrm{NO}_{3}\right)_{2}$. Arrows on the left section point to the thin reaction product and arrows on the right section to the beaded reaction product. Ultrathin section. (b) Electron spectroscopic imaging (ESI) of phosphorus. Arrows point to phosphorus-rich structures similar to those shown in $(a)$.

(encircled in Fig. $3 b$ ) showed a typical energy loss at $132.5 \mathrm{eV}$. Using this technique and the specific energy loss for phosphorus, phosphorus stores were also detected and mapped in association with the inner cell membrane without specific staining (Fig. $4 b$ ). Thus, we were able to confirm the results shown in Fig. 4(a) by the ESI technique (Fig. $4 b$ ).

\section{Discussion}

Our results describe and characterize for the first time poly $\mathrm{P}$ structures in $H$. pylori. These structures were demonstrated in cultured organisms as well as in those found in gastric and duodenal tissue. The presence of poly $\mathrm{P}$ has been reported in more than 100 different species of bacteria (Harold, 1963; Friedberg \& Avigad, 1968; Noegel \& Gotschlich, 1983; Skorko, 1989; Kjeldstad et al., 1991) but so far has been described for $H$. pylori by our group only. Although these structures are visible in numerous published electron micrographs of $H$. pylori, they are not further mentioned or discussed. Similar structures are found in the Helicobacter species $H$. mustelae, $H$. felis, $H$. suis, $H$. nemestrinae and $H$. heilmannii (Fox et al., 1989; Fox \& Lee, 1989; Bronsdon et al., 1991; Paster et al., 1991).

Metachromatic staining and the typical sublimation characteristics after exposure to the electron beam, as well as the elemental composition clearly identify the structures observed by us as polyphosphates.

However, not all bacteria within a population of $H$. pylori show poly $\mathrm{P}$ granules and not all such granules have the same morphological appearance. This suggests that the granules develop in a distinct phase of the growth cycle of $H$. pylori and accumulate under certain growth conditions. Some organisms such as Aerobacter aerogenes accumulate poly $\mathrm{P}$ only under conditions that are adverse for growth (Harold, 1963), whereas others, such as Pseudomonas shermanii, appear to accumulate poly P during exponential growth (Kulaev \& Vagabov, 1983). However, other workers consider that during exponential growth nucleic acid synthesis inhibits polyphosphate deposition and stimulates its degradation so that no significant poly $\mathrm{P}$ accumulation can occur (Lyons \& Siebenthal, 1966; Rao et al., 1985).

It is likely that there are different functions for poly $\mathrm{P}$ in different organisms and for any individual organism these structures may have several functions (Harold, 1966; Kulaev \& Vagabov, 1983). This may be due to the specialized localization of poly P. The most prominent pool of poly $\mathbf{P}$ is the intracytoplasmatic polyphosphate granule. This structure may truly represent a reservoir for stored energy and phosphorus and may be regarded as an alternative energy source when ATP is in short supply (Dawes \& Senior, 1973). Poly P has a low solubility in water and therefore does not affect the osmotic pressure within bacteria (Wood \& Clark, 1988).

Besides the large globular particles within the cytoplasm, the other locations are of special interest: the small electron dense particles close to the flagellar insertion and the smaller aggregates in association with the membranes. Energy stored in poly $\mathrm{P}$ close to the flagellar pole may be essential for processes like the energy consuming motility of $H$. pylori (Berg \& Turner, 1979; Cobley \& Cox, 1983). Poly $P$ aggregates in association with the cell membrane may be involved in maintenance of the integrity of the cytoplasmic membrane (Skorko, 1989).

Poly $\mathrm{P}$ located in association with the cytoplasmic 
membrane could be detected only by the sensitive method of ESI with the typical energy loss for phosphorus. Histochemical staining methods cannot demonstrate such small amounts of aggregated phosphate. Staining with $\mathrm{Pb}\left(\mathrm{NO}_{3}\right)_{2}$ can only detect large aggregates (Fig. $4 a$ ) and others may be solubilized and washed out during the preparation steps for conventional electron microscopy (Tijssen et al., 1985).

In conclusion, our results demonstrate poly $\mathrm{P}$ aggregates in at least three different pools of $H$. pylori. Their physiological function in $H$. pylori is believed to play a role which embraces energy reserve, phosphorus reserve and metabolic regulator purposes.

We thank Mrs Christine Attenberger for her skilful assistance in preparing this manuscript.

\section{References}

BAUER, R. (1988). Electron spectroscopic imaging: an advanced technique for imaging and analysis in transmission electron microscopy. Methods in Microbiology 20, 113-146.

BeRG, H. C. \& TURNER, L. (1979). Movement of microorganisms in viscous environments. Nature, London 278, 349-351.

Bode, G., Malfertheiner, P. \& Ditschuneit, H. (1988). Pathogenetic implications of ultrastructural findings in Campylobacter pylori related gastroduodenal disease. Scandinavian Journal of Gastroenterology (Supp. 142) 23, 25-39.

Bode, G., Malfertheiner, P., Mauch, F. \& Ditschuneit, H. (1991). Stored phosphate in H.pylori may be derived from phospholipid structures of the mucus layer. European Journal of Clinical Investigation 21, 31 (abstract no. 162).

Bronsdon, M. A., Goodwin, C. S., Sly, L. I., Chilvers, T. \& SCHOENKNECHT, F. D. (1991). Helicobacter nemestrinae sp. nov., a spiral bacterium found in the stomach of a pigtailed macaque (Macaca nemestrina). International Journal of Systematic Bacteriology 41, 148-153.

BuCK, G. E. \& SMITH, J. S. (1987). Medium supplementation for growth of Campylobacter pyloridis. Journal of Clinical Microbiology 25, 597-599.

Conley, J. G. \& Cox, J. C. (1983). Energy conservation in acidophilic bacteria. Microbiological Reviews 47, 579-595.

Dawes, E. A. \& Senior, P. J. (1973). The role and regulation of energy reserve polymers in microorganisms. Advances in Microbial Physiology 10, 135-266.

EISENBACH, M. (1990). Functions of the flagellar modes of rotation in bacterial motility and chemotaxis. Molecular Microbiology 4, $161-167$.

Fox, J. G., Chilvers, T., Goodwin, C. S., Taylor, N. S., Echmondo, P., SLy, L. I. \& BrenNer, D. J. (1989). Campylobacter mustelae, a new species resulting from the elevation of Campylobacter pylori subsp. mustelae to species status. International Journal of Systematic Bacteriology 39, 301-303.

FoX, J. G. \& LEE, A. (1989). Gastric Campylobacter like organisms: their role in gastric disease of laboratory animals. Laboratory Animal Science 39, 543-553.

FriedberG, I. \& Avigad, G. (1968). Structures containing polyphosphate in Micrococcus lysodeikticus. Journal of Bacteriology $\mathbf{9 6}$, $544-553$.

Harauz, G. \& OtTensmayer, F. P. (1984). Nucleosome reconstruction via phosphorus mapping. Science 226, 936-940.

HAROLD, F. M. (1963). Accumulation of inorganic polyphosphate in Aerobacter aerogenes. Journal of Bacteriology 86, 216-221

HAROLD, F. M. (1966). Inorganic polyphosphates in biology: structure, metabolism and function. Bacteriological Reviews 30, 772-794.

Hazell, S. L., Lee, A., Brady, L. \& Hennessy, W. (1986). Campylobacter pyloridis and gastritis: association with intercellular spaces and adaption to an environment of mucus as important factors in colonization of the gastric epithelium. Journal of Infectious Disease 153, 658-663.

JENSEN, T. E. (1968). Electron microscopy of polyphosphate bodies in a blue-green alga, Nostoc pruniforme. Archiv für Mikrobiologie 62, $144-152$.

Kueldstad, B., Heldal, M., Nissen, H., Bergan, A. S. \& Evjen, K. (1991). Changes in polyphosphate composition and localization in Propionibacterium acnes after near-ultraviolet irradiation. Canadian Journal of Microbiology 37, 562-567.

KulaEv, I. S. \& VaGabov, V. M. (1983). Polyphosphate metabolism in microorganisms. Advances in Microbiological Physiology 24, 83-169.

Lyons, J. W. \& Siebenthal, C. D. (1966). On the binding of condensed phosphates by protein. Biochimica et Biophysica Acta 120, 174-176.

NoEgel, A. \& GotsChlich, E. C. (1983). Isolation of a high molecular weight polyphosphate from Neisseria gonorrhoea. Journal of Experimental Medicine 157, 2049-2060.

Paster, B. P., Lee, A., Fox, J. G., Dewhirst, F. E., Tordoff, L. A. Fraser, J. G., O'Rourke, J. L., TAylor, N. S. \& Ferrero, R. (1991). Phylogeny of Helicobacter felis sp. nov., Helicobacter mustelae, and related bacteria. International Journal of Systematic Bacteriology 41, 31-38.

RaO, N. N., Roberts, M. F. \& Torriani, A. (1985). Amount and chain-length of polyphosphates in Escherichia coli depend on cell growth conditions. Journal of Bacteriology 62, 242-247.

Skirrow, M. B. (1977). Campylobacter enteritis: a "new" disease. British Medical Journal 2, 9-11.

SkoRko, R. (1989). Polyphosphate as a source of phosphoryl group in protein modification in the archaebacterium Sulfolobus acidocaldarius. Biochimie 71, 1089-1093.

Tussen, J. P. F., Van Steveniuck, J. \& De Bruijn, W. C. (1985). Cytochemical staining of a yeast polyphosphate fraction, localized outside the plasma membrane. Protoplasma 125, 124-128.

TompKins, D. S. (1989). Survival and growth of Campylobacter pylori. In Campylobacter pylori in Gastritis and Peptic Ulcer Disease, pp. 24-30. Edited by M. J. Blaser. New York: Jgaku-Shoin Medical Publishers.

Westblom, T. U., Madan, E. \& Midkiff, B. R. (1991). Egg yolk emulsion agar, a new medium for the cultivation of Helicobacter pylori. Journal of Clinical Microbiology 29, 819-821.

WOOD, H. G. \& CLARK, J. E. (1988). Biological aspects of inorganic polyphosphates. Annual Review of Biochemistry 57, 235-260. 